\title{
Ethical behavior within the public cadaster in Macedonia: Is there a "light" at the end of the "Tunnel"?
}

\author{
Branko, DIMESKI, \\ St. Kliment Ohridski University- Faculty of Law, Rudnicka bb, Kicevo, 6250, Macedonia, \\ dimeskibranko@yahoo.com \\ Mladen, KARADZOSKI, \\ St. Kliment Ohridski University- Faculty of Law, Rudnicka bb, Kicevo, 6250, Macedonia,
}

\begin{abstract}
Every public sector reform must promote ethics in the eyes of the citizens. One of the most notorious examples of successful modernization of public sector institutions in Macedonia is the effective reform of the Agency for Real Estate Cadaster. Thus, the main objectives are concentrated around examining ethics as very important aspect in the overall results of the implemented reforms within the Agency. The scope of the research is to clarify these objectives and depends on the knowledge that already exists in the research literature on the Macedonian Agency for Real Estate Cadaster. Therefore, the research methodology relies on observation and content analysis of various governmental documents and research papers. The research results show that the successful implementation of the E-cadaster system enabled new sophisticated dimension in the delivery of e-services to the public (notaries, geodetic companies and municipalities), but most importantly, to the citizens. The accent was on ethical issues when communicating with citizens. The role of public managers has been of tremendous help in fostering ethical behavior within and outside the Agency. However, periodical citizen surveys showed mixed results about the work of different Agency's units located in different municipalities. As in the past, there are still cases of unethical behavior of managers and employees in the Agency. The conclusions impose valuable implications for future academic and practitioner research in the field. It seems that there is no "perfect" public organization when it comes to ethics. Moreover, it seems that human nature can not always get in line with the Weberian organizational hierarchy.
\end{abstract}

Keywords: Agency; public sector; reforms; behavior

JEL Classification: H3, H5, RO.

\section{Introduction}

"Ethics" has a Greek and Latin origin and most generally explained means values and carefully defined rules of behavior or rules of conduct. In addition, in the literature the concept it is also known as a part of the so-called moral philosophy or the study and analysis of the moral beliefs. Ethical and moral aspects are the source of law provisions but they are not the same. Different from the normative nature of the legal provisions, ethics is something to do with the human character that, in some cases, is completely irrelevant to law (Perry, 2000).

The Code of Ethics and the Code of Conduct are universally accepted documents in public sector organizations. In democratic societies, most (not to say all) public organizations are legally obligated to prepare, to adopt and to implement Code of Conduct (Government of Western Australia, 2016).

In June 2014, the UK Committee on Standards in Public Life published the "Ethical standards for providers of public services". The publication is one of the best worldwide examples of defining and clearly regulating the public sector behavior by setting seven principles of public life that apply 
to every public sector employee. Those are selflessness, integrity, objectivity, accountability, openness, honesty and leadership. Within this ethical framework, the public service employees must act in promoting good behavior in the eyes of citizens and to openly challenge all forms of poor acting in public sector institutions (Committee on Standards in Public Life, 2014).

The so-called "Ethical Framework" is a subject of permanent research and development worldwide with the unique goal of "serving for the people and promoting public interest". The Australian Public Service Commission (Government of New South Wales, 2013) developed a very good example of Ethical Framework through the years.

In the literature, public sector ethics is a very broad topic. Different ethical values and moral issues characterize different cultures. However, in recent years the foundation of public sector ethics is streaming towards defining a common ground worldwide. Thus, so-called "government ethics" or "regulatory ethics" means a respect for ethical rules in governmental institutions. It refers to wide array of issues such as transparency, corruption, bribery, conflict of interest, open data, open government etc. (Santa Clara University, 2000). It is extremely important to impose an ethical climate in public sector institutions that refers to the various circumstances of the working places that can influence the process of decision-making (Shacklock, Manning, \& Hort, 2011).

Since Macedonian independence in 1991 until now, the governmental efforts to adopt good ethical practices in public sector institutions were tremendous. In doing that, the system of public cadaster was not "out of the game". During the time and especially in the last few years, the Agency for Real Estate Cadaster (next AREC in the text) undertook very serious reforms regarding the permanent improvement of the quality of their professional relationships with the citizens. Besides all that, for a small country as Macedonia there is still a growing number of criminal and corruptive behavior of the public employees in AREC. The following sections of the paper show an overview of the general public sector reforms, as well as the AREC recent reforms, regarding ethics. The last section deals with examples of public sector ethical misconduct of the public cadaster employees.

\section{Public administration reform efforts: What has been done to reduce unethical behavior in public institutions?}

Since the country's independence in 1991, there were many efforts to establish ethical behavior of the public employees. However, the two most important steps towards official promotion and enactment of some ethical guidelines in public sector institutions were undertaken by the Strategies of Public Administration Reform, adopted by the Governments in 1999 and 2010. Among other principles, one of the central questions of both strategies was the "fight" against corruption and unethical related behavior in public sector institutions.

\subsection{The reform package from 1999}

The first very serious step towards reforming public sector institutions in Macedonia was undertaken in May 1999 when the first Strategy of Public Administration Reform, since its independence in 1991, was officially adopted. This very important document defined many activities that were planed to be implemented in coordination with various public sector institutions on different governmental level. The main intentions of the reform were defining and implementing modern solutions within administrative structures and processes with the purpose of promoting democratic values and market principles in the economy. In order to achieve that, the reform principles were set in order to promote and to further develop professionalism and ethical behavior in public sector institutions. Generally, those principles were in line with the main national 
aspirations of the country toward the process of full membership in the European Union (Dimeski, 2011).

The reform efforts of the strategy put the accent on the following principles i.e. a) Rule of law; b) Competency; c) Efficiency; d) Stability; e) Predictability; f) Responsibility; g) Equal treatment; h) Transparency; and i) Ethics (Markic, 2004). Consequently, they are universal principles of so-called good governance practice and is very hard, or almost impossible, to exclude any of them because of their connectivity and similarity. For example, public sector transparency points out that the there is no administrative discretion or any information privilege given to certain public or private legal entity. The principle of ethics, together with the other principles (such as rule of law, transparency, equal treatment, competency etc.) is a key determinant during the process of developing democratic values and confidence in public sector institutions in the eyes of the citizens. However, besides the best intentions, the strategy ended as a big failure. More precisely, the failure of the strategy was exactly during the implementation phase because of several reasons, such as lack of coordination, finances and all other needed political and technical support (Analytica, 2007). Because of the failure of the strategy, the country continued to suffer from political, economic and ethical point of view. Public sector institutions faced moral crises and erosion of mass confidence from the public.

\subsection{The recent reform from 2010}

After the failure of the strategy in 1999, the Government of the Republic of Macedonia during December 2010 adopted the most recent Strategy for public administration reform (20102015). In the meantime, the Government established the so-called Ministry of Information Society and Administration that in coordination with the other public institutions played a major role during the process of preparation and adoption of the new Strategy for public administration reform (201015). As can be seen from the Table 1 below, the Strategy focused on 4 different areas i.e. public finances, human resource management, e-government $\&$ management and corruption (Ministry of Information Society and Administration, 2010).

Table 1. Main areas of economic implication of public administration reforms (December, 2010)

\begin{tabular}{ccccc}
\hline $\begin{array}{c}\text { PA } \\
\text { Reform }\end{array}$ & Public Finances & $\begin{array}{c}\text { Human } \\
\text { Resource } \\
\text { Management }\end{array}$ & $\begin{array}{c}\text { E- Government } \\
\text { and E- } \\
\text { Management }\end{array}$ & Corruption \\
\hline & $\begin{array}{c}\text { Budget } \\
\text { Preparation }\end{array}$ & $\begin{array}{c}\text { Human } \\
\text { Resource } \\
\text { Planning }\end{array}$ & $\begin{array}{c}\text { E-Infrastructure } \\
\text { Human }\end{array}$ & $\begin{array}{c}\text { Abuse of } \\
\text { Public } \\
\text { Resources }\end{array}$ \\
& Public & E- Public & Conflicts of \\
Procurements & Resource & Services & \\
& Interest & \\
Internal & Humaning & & \\
Financial & Resource & & \\
Control & Evaluation & & \\
External & System of & & \\
Financial & Salaries and & & \\
Revision & Benefits & & \\
\hline
\end{tabular}

Source: Dimeski, B. 2011. Public Administration Reform Process in Macedonia: Between Politics and Good Governance,International Journal of Politics and Good Governance, Vol. 2, No. 2.4 Quarter IV, p.7.

In addition, during October 2012, the Ministry of Information Society and Administration (next MIOA), adopted so-called "Revised Action Plan of the Strategy for Public Administration 
Reform (2010-2015)" that was prepared for a middle run. There are a number of measures where AREC together with the other public institutions had an active role. Under the measure "Introducing a system for measuring the satisfaction of the users of administrative services- evaluating the administration", AREC was directly involved in different ways (e.g. installing of sample instrumentssemaphore, introducing recommendations for improvement and updating the system with central software solution)". Next, within the measure "Introducing a register of public employees and defining the overall number of the employees in public administration", the AREC was involved during the process of purchasing and the implementation of the software solution for the public sector registry and completing the register of public employees with the data about public sector employees. Within the measure "Simplifying the internal mobility of the public sector employees", AREC was active by modifying the appropriate legal provisions. Next, AREC was directly involved in the setting of the following reform measures:

1. "Improving the coordination mechanism for managing the human resources" on the level of whole administration; "Introducing a strategic level for human resources planning";

2. "Developing information system for human resources management";

3. "Forming a new organizational form for training of the administration";

4. "Forming a system for micro-learning";

5. "Connecting and using of the registries and databases between state bodies and institutions or developing inter-operability";

6. "E-payments of the administrative taxes and fees";

7. "New state programme for prevention and repression of the corruption with appropriate Action Plan"; and

8. "Proactive implementation of the anti-corruption legislation" (for example Ethical Code for public and state employees) (Ministry of Information Society and Administration- Revised Action Plan of the Strategy for Public Administration Reform, 2012).

\section{Legal provisions and ethical codes}

During time, the public administration legislation and institutional mechanisms for its implementation gradually evolved including many law provisions that pertain to ethical behavior of public sector employees. In 2000, the Agency for State Employees was founded by the Government as a first serious and professional institution in the field. The Agency was active until 2011, when transformed to the current Agency of Administration. Meanwhile, in 2010 a new Ministry called Ministry of Information Society and Administration was formed in order to synchronize, coordinate and implement all necessary legal provisions and projects for permanent reform and modernization of the public sector in the country.

The most important legislation on ethical behavior of public sector employees consists of: The Law of Administrative Servants adopted in 2014 (Official Gazette of the R.M., No. 27 from 05.02.2014) and the Law on Public Sector Employees adopted in 2014 (Official Gazette of the R.M., No. 27 from 05.02.2014) (Ministry of Information Society and Administration, 2016). A number of general Ethical Codes were prepared and adopted by the governmental institutions, such as: Code of Ethics for State Servants (Official Gazette of the R.M., No. 129, from 23.09.2011); Code of Ethics for Public Servants (Official Gazette of the R.M., No. 133 from 30.09.2011) and Code of Administrative Servants (Official Gazette of the R.M., No. 183 from 12.12.2014). In addition, a number of specific Codes of Ethics were prepared and adopted by separate public institutions.

As noted above, there is a rich legislative base adopted by the officials through the years. However, there are still a number of cases for unethical and unprofessional behavior of the public 
employees. Thus, the paper provides examples of unethical behavior of the public employees. The reasons are different, going from "laughable" to "extreme" situations.

\section{Public cadaster reforms: Towards more efficiency, effectiveness, transparency and open access}

During the years, the Agency for Real Estate Cadaster was permanently developing with a huge support from the Governments in Macedonia. The further development of the real estate cadastre system in the country was an inevitable process. A sustainable, effective, efficient and transparent cadaster points to a greater contribution to the overall development of the national economy, especially from two important points of view: a) attracting domestic and foreign investments in the national economy; and b) legal security of the ownership rights of the real properties. In fulfilling the above mentioned goals, the AREC received a huge and permanent political, financial and technical support from Macedonian Governments as well as from other important international organizations worldwide, such as: World Bank (through the REC project), Netherlands (through so-called MATRA program), Sweden (through SIDA Agency) etc. (Gruevski, 2014).

One of the general aims of all these official support was to achieve better transparency, trust and increased confidence from the citizens and businesses in AREC operations. Without any doubts, the introduction as well as the overall implementation of the E-cadaster system proved to be very successful to municipalities or the AREC Departments countrywide ( 29 in total), public notary services as well as private geodetic companies and surveyor professionals. Some of the great achievements of professional workers in AREC towards transparent and ethical behavior are the easy and open access to all the necessary data (e.g. information on land, buildings or owners on modernized AREC website), the effective and efficient application procedure for different transactions (enabled bythe public Notary offices without coming to AREC Departments)(ARECDepartments, 2016).

AREC, as a legal entity, subordinates to the Government and works under the Law on Real Estate Cadaster adopted in 2013 (published in Official Gazette of R. Macedonia No. 55/13) and other related legislation. According to Article 8 of the Law on Real Estate Cadaster, the main responsibilities of the Agency are:

- Establishment and management of geodetic-cadaster information system;

- Performance of basic geodetic works;

- Real estate survey;

- Registration of real estate rights;

- Establishment and maintenance of real estate cadaster;

- Geodetic works for special purposes of significance to Macedonia;

- Production of state topographic maps;

- Administration of a Spatial Units Register;

- Establishment, maintenance and public access to the National Spatial Data Infrastructure;

- Establishment and management of graphic registry of construction land and administration of graphic registry of streets and house numbers; and

- Supervision over the work of the sole proprietors-authorized surveyors and trade companies for geodetic works (Law on Real Estate Cadastre, 2013). 
As every public institution in Macedonia, in executing its responsibilities, the Agency must fully adhere to the principles of liability, competency, professionalism, efficiency, effectiveness, transparency and ethics.

From over a million items received by the Agency earlier this year, 44 percent of the cases were, so far, sent through the electronic counter. That means that more than 440,000 items are electronically received, or half of the total population did not need to come personally in the cadaster or completed the work in the municipality, notary public or a private surveying company. Thanks to the electronic cadaster, the needed time of resolving the individual or group cases was radically reduced. If in 2005 , the average time for registering the purchase of an apartment was over90 days, now it was reduced to six hours, and the same applies for mortgage registration. As a result, over 700 professionals from cadaster departments undergo professional training in using the electronic desk. Changes in several laws drastically reduced the procedure, duration and cost of issuing building permits. For a comparison, issuing the Property List in 2005 costed around 350 denars (or approximately 5.7 euros) and now the overall electronic deed costs 150 denars (or around 2.5 euros) (Sitel-daily news, 2015).

In 2013 was implemented a pilot project "One Stop Shop for issuing construction permits" within the Ministry of Transport and Communications. The success of the project was "translated" as the request for building permits to be submitted in electronic form through public web portal (signed with a valid digital certificate, issued by a licensed publisher with all other required documentation that must be scanned or digitally signed). As a result, until October 2015were submitted360,000 requests for legalization of illegal buildings. Moreover, 135,000 buildings were officially certified and a total of 200,000 geodetic reports and studies were developed by the private geodetic companies (Sitel-daily news, 2015).

In recent years, the latest significant developments as part of AREC reforms are noted as following:

- The establishment of so-called MAKPOS GNSS network system as a modern system developed according EU international standard that makes a great scientific contribution of the accuracy of the geodetic surveys. 14 GNSS stations that are evenly distributed across the country help the geodetic practice in Macedonia in many different ways;

- Implementing a pro-reform oriented cadaster legislation that in 2005, with the adopted changes in the Law on Survey, Cadaster and Registration of Real Estate Rights, gave the right for a legal registration of private geodetic companies as well as official surveyors with a license of professional expertise in the field of geodetic practice;

- The increased number of legalized or registered real estate properties grew rapidly in the last years. Thus, AREC succeeded in further proceeding of all the submitted applications by quick registration of all the required transactions on a daily basis. The impact on the economy was in the rapid growth of mortgage loans that in 2012 equaled approximately 5 billion euros;

- The level of transparency and public confidence in AREC was subsequently increased with the successful launching of the event called "Open Days with the Cadaster". The event is organized since 2007 and the citizens have the opportunity to meet and talk with the AREC managers and ask to meet other cadaster professionals, in order to 
present their problems, challenges or solutions. The event is organized according to a previously adopted program, on annual basis;

- The re-design of AREC web portal, because of the launch of new products and services, as well as the growing public "pressure" for greater transparency, efficiency and effectiveness of AREC operations. The AREC web-site has been gradually enriched with all the necessary information about the land, buildings and owners. Most of AREC services and transactions are electronic and must be pointed out that the redesign of the web portal was a great beginning of the concept of E-cadaster system that AREC, in coordination with the private geodetic companies, public notaries and municipalities started to develop since 2007;

- Through the years, AREC permanently invested in IT development for many purposes. However, one of the greatest contribution is the successful implementation of the Ecadaster system (so-called eKat) as a modern and sophisticated system for guaranteeing the real estate property rights in the country; and,

- The AREC IT developments contributed to the overall positive climate for doing business in Macedonia. For example, in 2016 the country ranked 50 out of 189 countries in the world, according to overall conditions for registering property. In addition, Macedonia stands at 10th place out of 189 economies in dealing with a construction permits (Doing Business Report 2016). The ranking numbers point out the great efforts and results achieved through the years thanks to AREC reforms (Gruevski, 2014).

In addition, in June 2016, the AREC Director publicly announced that the Agency successfully introduced three innovations in order to promote better quality when communicating with citizens. Those are:

- The introduction of the on-line service that enables the clients to call or to write an email about any technical error, without coming personally at the front desk at the Department of cadaster;

- "Make an appointment", that offer the clients a possibility to schedule a meeting with the public employees over phone or e-mail; and

- The module "Campaign" enables mass information of the citizens about the current innovations and challenges of the cadaster operations. In addition, it gives a great possibility to conduct periodical survey research about the citizen's satisfaction on the offered and implemented cadaster services (NovaTv- press news, 2016).

\subsection{The research on customer satisfaction}

During June and July 2014, the Ministry of Information Society and Administration conducted a survey called "Barometer of institutional quality", in three randomly selected municipalities, in order to measure the citizen's satisfaction on the received public services. Respondents answered that the longest waiting time in order to get the required service they experienced in AREC Departments. As a result, the Ministry announced a preparation of an Action Plan to be adopted by 
the Government in order to undertake a more serious official measures towards eliminating the overall weaknesses that were noted in the survey (A1on- daily news, 2014).

In August 2014were published the most recent survey results of the public cadaster work across the country. According to the survey, the AREC Departments in Ohrid and Kavadarci registered best results, as opposed to Tetovo, Gostivar and Kriva Palanka that showed poorer results. The survey, coded under the name "Secret Client" was prepared and implemented by the Ministry of Information Society and Administration. The clients assessed that the slow administrative procedures and unkindness of the front desk employees were the biggest problems in AREC Departments in Tetovo, Gostivar and Kriva Palanka. According to clients, the longest waiting time was registered in the Department in Tetovo while the shortest in Ohrid i.e. 5 to 15 minutes. The results of the survey were a motivation for the Minister to visit the Departments with poor survey results and to talk with the managers of how to overcome the registered problems in their Departments. In addition, the Minister threatened that if AREC Department did not undertake any appropriate measures to improve the working process, he will be enforced, according to the law, to penalize the employee with 3000 euros, the Department manager with 6000 euros and the Director of AREC with a 15000 euros. He encouraged the citizens not be afraid and to visit the Ministry or the Administrative Inspectorate if they feel that they have problems in any of AREC Departments across the country. In addition, the Director of AREC pointed out that besides the reform efforts, these Departments will be under his personal control and he will impose them additional reform measures in order to improve the overall picture of the working results (Press24- daily news, 2014).

In the meantime, for the better access of the citizens to AREC services, a contact centres recently opened. Itis available during the working time (from 8:30 a.m. until 16:30 p.m). The citizens can call for free by using the "open phone line" to denounce any type of unethical behavior, corruption or bribery as well as to get some new information about the current status of their application. Furthermore, this mechanism guarantees discretion of every citizen that can help in fighting corruption and every other form of unethical behavior within AREC (Agency for Real Estate Cadastre, 2016).

The contact-center operates under the principle "first called, first served" and there are language options (Macedonian, Albanian and English). In addition, there is an option of active registration of the missed phone calls and regarding that the employees in the AREC contact center have the responsibility to call back the clients in order to get the necessary service they called for before. According to reports, from May until December 2014, there were 13,440 citizen calls for various purposes. One of the biggest contributions of the contact-center is that it gives a possibility for monitoring and online tracking of the client satisfaction on the work of AREC as well as implementing various surveys in order to get detail information about the cadaster performances. As a result, in February-March 2015, the survey called "Your Opinion about Us-To a Better Service for You" was implemented and lasted for 30 days. The survey consisted of four basic questions and was available to citizens on the front desks in all cadaster Departments in the country as well as in daily newspapers (Republika- daily news, 2014). The clients had the opportunity to send their answers in many different ways and the employees from the AREC contact center were responsible for making analysis of the answers by accepting those suggestions that can help AREC in developing ideas and projects for the future (Denar- daily news, 2015).

\section{Ethics in AREC: Examples of unsuccessful stories in ethics}

This study presents some of the unlawful behaviors in public cadaster in Macedonia, as an evidence of unethical behavior in practice. 
On March 1st 2014, it was publicly announced that public officials from the department of AREC in the Municipality of Negotino were arrested and charged for bribery and corruption related issues on their workplaces. More precisely, the Office of the public prosecutor from Kavadarci submitted an official crime conviction against two AREC public employees for "receiving bribery", according the Article 357 of the Criminal Code of Macedonia. They used their public position in AREC with the intention and purpose to gain unlawful gains. They accepted $€ 400$ euros in order to register in a cadaster books a house and a store without appropriate request and without previously prepared official geodetic report, as opposite to the official Law on Real Estate Cadaster in Macedonia (JUSTICIA- Law information portal, 2014).

In July 2015, the Department for Organized Crime and Corruption submitted an official crime conviction against the Manager of the AREC Department in Kavadarci (because of the existence of a reasonable doubt for committing a crime connected with abuse of the official position and authority)and against other Manager of the legal entity in the private sector (for existence of a reasonable doubt for committing a crime connected with "encouraging" other person or entity in committing a crime). What actually happened? According to organized crime police reports, during 2004, now the ex-Manager, by using his working position in the Department, made changes in the ownership structure opposite to legal provisions. In other words, he altered the ownership structure of a 3.592 M2 piece of land, for a legal entity named "Koding" that previously was in state ownership without the existence of any legal base for doing such activities. After almost 11 years, in 2015, an illegal action was revealed: the Manager of the Department tried to correct his initial decision in 2004 and committed another illicit action, since the correction was under mortgage. Overall, by this unethical and illicit behavior, the Manager enabled a legal entity to get state resources (or land), as opposed to the law, by abusing his position in AREC Department in Kavadarci (MKD- daily news, 2015).

During December 2015, the police arrested 19 people in a mass police action coded under the name "Geodet". Nine of them were actual employees in AREC, two former employees in AREC, one private owner of a geodetic company and seven other people that illicitly gained the real estate. It is interesting that, according to news reports, the main organizer of the criminal scheme was a 33year old law graduate whom recently worked in AREC Department in Skopje. Under her "leadership" of the criminal scheme, there were involved a number of geodetic workers, three public cadaster managers working in AREC and a number of teller workers in AREC. According to the police reports cited by media sources, the opposite to law registration of the real estate ownerships, were very simple and executed in two different ways. By abusing his working position in AREC, one of the managers opened a public file for a fictive correction in the cadaster and after that, he illegally directly appointed the subject to the "leader" of the group, that brought the final decision about what should be registered in the cadaster books (instead of appointing a surveyor). The second way was characterized by submitting the so-called fictive or false documents from the now arrested people to a previously known teller worker in the cadaster. After the submission, the manager (now the suspect) transferred all the files that were opened according these false documents to the 33year "leader" of the criminal group. By performing this unethical behavior, from the end of 2014 until the middle of 2015, the suspected criminal group in AREC and outside of AREC abused a total of $€ 5$ million euros public money. In other words, they succeeded to unlawful register a total of 140000 square $\mathrm{km}$ of land and a building in Skopje suburb of Vodno that was built without proper technical documentation (Sitel- daily news, 2015).

In July, 2016 the AREC Department in Skopje during a regular internal control from the Sector of Control and Oversight revealed a number of unlawful employees behaviors. Between 2013 and 
2016, the employees in the cadaster, as opposed to the law, stole a total of 1.883.433.00 MKD Denars or around $€ 30000$ euros. By offering their credit cards to clients that did not have credit cards for payments in POC terminals that were put at the switches, the employees offered and use their credit cards in order to make payments for them and after that they asked for cash for doing that. After they received the cash from the clients, instead of processing the transactions they reverse all the transactions. In other words, they put all the money in their private "pockets" instead of transferring them to the official bank account of AREC (Business News, 2016).

Going beyond, in 2004 the news published an interview with the Director of the Centre of State Geodetic Authority (now AREC), where it was acknowledged that corruption is present in the cadaster institutions. At that time it was called and pretty much known under the name "Cadastre Mafia": for a certain amount of money or political favours of different types, the cadaster mafia has the ability to illegally "award" you with a property. The citizen's rumours from that time pointed out that the "pricelist" for "buying" a favour or illegal service from the cadaster officials ranged from 100 to $500 €$, depending on the complexity of the cadaster service illegally provided.

During 2003 and 2004, according the police reports released in the news from that time, there were two working suspensions of cadastre managers in Gevgelija and Makedonski Brod Departments. In addition, many cadastre public workers were under surveillance and investigation by the police for behaviours opposite to law.

The "integrity" of the Cadastre was demonstrated by a case where a citizen who wished to remain anonymous in that time, almost lost his yard. The story began in 1999, when the yard that was state land was illegally transferred to his neighbour by the cadaster officers. When the citizen went in 2002 to the Land Registry to inform the purchase of his part of the yard he saw the fraud. When he asked officers how his yard was transferred to the name of the neighbour, they answered it was because the neighbour brought a gift from the land user. Obviously, they lied to him. After that, the citizen explained that it was not possible because the mentioned neighbour deceased almost 30 years. When he asked the cadaster manager to show that document for a gift, the current director of the Skopje Cadastre admitted that there is no such. The manager apologized to the citizen and added his name on the official document for ownership. After that, when the citizen reacted to the manager that even a small child can use pen in such a manner, the manager apologized again and signed and sealed the correction. What can be said after this case? The cadaster officials, in their unethical behaviors went to extremes i.e. they tried to "resurrect" a dead man in order to "award" a living man with the yard.

Finally, one of the biggest cadastral affairs that became top news were forged documents for "villa of Vodno" who began to build for the sister of the wife of former Prime Minister Ljubco Georgievski. Deeds for the plot on which the villa was built overnight were transferred from one to another name in order to hide that the villa was built for the Prime Minister relative. The cadaster manager because of forging an official document was sentenced to one year in prison. In addition, four other employees in the cadaster were accused and two others were convicted. The Head of automatic processing in Skopje Department of Cadaster was sentenced to six years in prison and three months in prison received the cadaster recorder. According to Annual Report released in 2003 by the Ombudsman Office, the total number of complaints submitted for the work of the cadaster services in that time equalled to 80 . From that number, 32 cases or $37.31 \%$ registered unlawful behaviors by the cadaster officials (Vest- daily news, 2004). 


\section{Conclusions}

Macedonia has already adopted a good and rich legislation on ownership rights of the real estate properties. In addition, the already well developed IT system that supported the successful implementation of the E-cadaster system within the AREC contributed for the overall economic development in the country by accelerating a large scope of transactions that are connected with the property registration and all other cadaster-related services. As was mentioned above, the main business partners of AREC are public notaries and private geodetic companies. The municipalities, notaries and geodetic companies launched so-called electronic front desks for clients. In doing that, they are connected with the E-cadaster system from which they get all the necessary information in order to prepare the documents and to send them electronically to AREC in order for their application to be put on a processing list by the AREC officer.

The public surveys on AREC work performances implemented since2006, showed increased public confidence. The clients pointed out the transparency, free access to data and services as well as the possibility that AREC offer to is clients to monitor at any time the progress of their submitted application. Overall, the recent developments of AREC, supported by a number of successfully implemented projects point out as great evidence of a modern institution. It invested many efforts in good management practices, as well as in human resource recruitment and training, in order to successfully respond to the needs of the clients, as well as general citizenry in the country.

Besides successful reforms and money invested, the following central question regarding ethics in public cadaster in Macedonia still remains open and it seems that the theory and practice of public sector development in ethics related issues are not capable to provide best answers in near future: "Is there a light at the end of the tunnel?". The Weber's principle of ethical behavior within the ideal bureaucratic hierarchy is still utopia in Macedonian cadaster system and because of the different meanings of ethics, there will be still public employees in the cadaster that "do not like to read or can not read well" the Code of Ethics or the Code of Conduct in the AREC.

\section{References}

[1] A1on- daily news, http://a1on.mk/wordpress/archives/368805, date: 04.03.2016.

[2] Agency for Real Estate Cadastre, http://www.katastar.gov.mk/en/Faq.aspx\#faq6, date: 02.05.2016

[3] Analytica (2007), Evaluation of Public Administration Reforms in Macedonia, Analytica- Thinking Laboratory, Report No. 5, Skopje, Macedonia, pp. 1-20.

[4] AREC- Departments, http://www.katastar.gov.mk/en/Page.aspx?Page=oddelenie_en\&m=1471, date: 12.03.2016.

[5] Business News, http://www.biznisvesti.mk/vraboteni-vo-katastar-napravile-kriminal-vreden-1-9-milioni-denari/, date: 08.07.2016.

[6] Code of Administrative Servants, Official Gazette of the R.M., No. 183 from 12.12.2014.

[7] Code of Ethics for Public Servants, Official Gazette of the R.M., No. 133 from 30.09.2011.

[8] Code of Ethics for State Servants, Official Gazette of the R.M., No. 129, from 23.09.2011.

[9] Committee on Standards in Public Life (2014), Ethical standards for providers of public services, Committee on Standards in Public Life, London, pp. 1-37.

[10] Denar- daily news, http://denar.mk/72712/ekonomija/otvoren-kontakt-centar-na-agencijata-za-katastar, date: 18.07.2016.

[11] Dimeski, B. (2011). Public Administration Reform Process in Macedonia: Between Politics and Good Governance, International Journal of Politics and Good Governance, Vol. 2, No. 2.4, Quarter IV, pp. 1-14.

[12] Government of Macedonia: Ministry of Information Society and Administration (2010), The Strategy for public administration reform in the Republic of Macedonia 2010-2015, EuropeAid/127747/C/SER/MK, Sector of Policy Analysis and Coordination, pp. 1-77. 
[13] Government of Macedonia: Ministry of Information Society and Administration (2012), Revised Action Plan of the Strategy of Public Administration Reform 2010-2015, Midterm overview, pp. 1-32.

[14] Government of Macedonia: Ministry of Information Society and Administration (2016), Documents and Legislation, Official Gazette of the R.M., No. 27 from 05.02.2014.

[15] Government of New South Wales- Public Service Commission, https://www.psc.nsw.gov.au/workplace-culture--diversity/workplace-culture/the-ethical-framework, date: 13.07.2016.

[16] Government of Western Australia, https://publicsector.wa.gov.au/public-administration/public-sectorgovernance/good-governance-wa-boards-and-committees/resources/code-ethics-and-codes-conduct, date: 24.05.2016.

[17] Gruevski, G. (2014). Fostering transparency in land ownership, use and administration- Macedonian experience, proceedings of the 2014 World Bank Conference on Land and Poverty, Washington D.C., USA, pp. 1-21.

[18] JUSTICIA- Law Information Portal, http://justicia.mk/novost.asp?cnd=388, date: 24.05.2016.

[19] Law on administrative servants, Official Gazette of the R.M., No. 133 from 30.09.2011.

[20] Law on public sector employees, Official Gazette of the R.M., No. 183 from 12.12.2014

[21] Law on Real Estate Cadastre (2013), Article 8-Competences of the Agency, Official Gazette of the Republic of Macedonia, No. 55, Skopje, pp. 4-5.

[22] Markic, L. (2004). National Case-Study: Public Administration in the Republic of Macedonia, Centre for Public Administration and Public Policy, Euro-Balkan Institute, No. 45, pp. 17-29.

[23] MKD- news, http://www.mkd.mk/crna-hronika/po-greshka-11-godini-stopanisuval-so-drzhavno-zemjishte, date: 12.06.2016.

[24] NovaTv- Press News, http://tvnova.mk/vesti/ekonomija/otsega-i-elektronski-zakazhi-sostanok-i-prijavi-greshka-vokatastar/, date: 02.08.2016.

[25] Perry, L.D. (2000). Ethics in Public Service- Workshop on Leadership, Santa Clara University, Markkula Centre for Applied Ethics, Santa Clara, CA.

[26] Press24- daily news, http://www.press24.mk/anketa-taen-klient-ohrid-i-kavadarci-najdobri-tetovo-i-gostivar-sonajslabi-rezultati, date: 10.08 .2016$.

[27] Republika- daily news, http://republika.mk/389332, date: 30.08.2016.

[28] Santa Clara University, https://www.scu.edu/ethics/focus-areas/social-sector-ethics/resources/ethics-in-publicservice/, date: 11.09.2016.

[29] Shacklock, A., Manning, M., Hort, L. (2011). Ethical Climate Type, Self-Efficacy, And Capacity to Deliver Ethical Outcomes in Public Sector Human Resource Management, Journal of New Business Ideas \& Trends, Vol. 9, Issue 2, pp. 34-49.

[30] Sitel- daily news, http://sitel.com.mk/finansiskata-policija-otkri-kriminal-tezhok-nad-5-milioni-evra-vrshen-prekukatastarskite-knigi, date: 14.08.2016.

[31] Sitel- daily news, http://sitel.mk/trpeski-skrateni-troshoci-i-vreme-za-uslugi-so-elektronskiot-katastar, date: 14.08.2016.

[32] Vest- daily newspaper, http://star.vest.com.mk/default.asp?id=80301\&idg=4\&idb=1202\&rubrika=Revija, date: 21.08.2016.

World Bank. (2016). Doing business 2016: Measuring Regulatory Quality and Efficiency- Economy profile of Macedonia (FYR), The International Bank for Reconstruction and Development/The World Bank, Washington, USA, pp. 1-44. 